\title{
PSYCHOLOGICAL ASPECTS OF PERSONAL AND SPIRITUAL YOUTH GROWTH
}

\section{Zhyhaylo N. I., Snyadanko I. I., Hrabovska S. L. \\ "Personality begins with love", acad. Maksimenko S.D.}

\section{INTRODUCTION}

The concept of "personality" is diverse and multifaced. Personality is the subject of study of many sciences. Each science studies the personality according its specific aspect. For the psychological analysis of a person it is necessary to clearly distinguish the concept: "person", "individual", "personality", "individuality", "Person". The most general (philosophical definition) is the concept of "person" = "individual". Person is a biosocial being that possesses articulate language, consciousness, higher mental functions (abstract-logical thinking, logical memory, etc.) is able to create tools and use them in the process of social work. Individual belongs to the human race; biological organism; carrier of general hereditary qualities of a biological species, person. Representative of the human race - homosapiens. Any person - an individual, regardless of the level of his physical and mental health (for example, Mowgli, mentally ill, etc.). While the personality is a conscious individual who occupies a certain place in society and performs certain functions - a product of human intelligence. We become a personality under the influence of society, education, upbringing, correlation, communication, etc. Individuality unique peculiarity of every person's psyche (character, temperament, skills, peculiarities of the occurrence of mental processes, a set of feelings, etc.) that forms its uniqueness, difference from other people.

And finally, the Person with a capital letter is "What a Complete Creation-pearson!" (Shakespeare); "To become a man is an art" (Novalis); "Person reveils in his actions" (Schiemer). The idea of a strong person is most fully represented in the poetry and life of Lesya Ukrainka. Lesya ... A gentle girl with a blue sky in front of her eyes. Eternal legend. The fate did not send her jackets, because all her life was a long and exhausting war with the disease. However, in her poetry, she glorified the invincibility of the spirit of a strong personality.

\footnotetext{
${ }^{1}$ Максименко С.Д. Генеза здійснення особистості : наук. монографія. - К. : КММ, 2006. 255 с.
} 
"As I die, the fire of my songs is lit up in the world. And the flames of my songs are restrained. And the restrained scab that sows. It burns at night, it burns in the day". (From the collection "Dumas and dreams").

She was a clear ray breaking through the "darkness of the night", a bright star that illuminated the thorny path to freedom. "Laughing through tears" and "singing songs in the midst of evil" - this was the motto of her life, and it would be good if it became a guideline for every person. She proudly claimed: Who told you that I am weak, that I am obeying fate? Is my hand trembling? Are the song and the thought disabled? Her song, her thoughts, came to people to light those who are indifferent with fire, to wake up those who are memorable, to illuminate the path of the nation to the top of spirituality and beauty.

The Day newspaper in the person of Larisa Ivshyna forms strong personalities, clarifying today's problems, preserving national traditions, developing spirituality, honesty, and dignity. In this regard, Lina Kostenko has beautiful lines: "Another moment, another moment, only moment and moment, and I will look back, and this is years and years! So with the newspaper "Day": day, day, day, and suddenly you realize that "Day" is the newest history of Ukraine! So the newspaper "Day" is readed and waited". History gave us examples of strong personalities: G. Skovoroda, T. Shevchenko, I. Franko, L. Ukrainka, L. Kostenko, A. Sheptytsky, J. Slipy, L. Husar, B. Gavrylyshyn, I.Pulyuy and others like that. Ivan Franko in his poetry "From the Years of Youth" in a series of "heart-spirit-love" accurately connects "personality - language-nation". In our favorite contemporary, Lina Kostenko, there are the following words: "The most serious opposition is a decent, honest personality" (Legend "To be a vessel for you, or a sea?").

\section{Psychology of personal growth of youth}

Socialization of the individual is carried out in social groups, in which a person is consistently included throughout life. Influence on a person's social environment through social groups is mediated by the psychological properties of a person - the type of nervous activity, instincts, temperament, abilities, character, value orientations. It is through the interaction of these beginnings - psychophysiological, natural and social - the personality is formed.

In society there are certain channels, levers of socialization. This is education, education through educational establishments, through cultural institutions, mass media, family, literature, art, computer network Internet, 
etc. If an individual is born, then the person becomes in the process of socialization. Socialization is the process of the individual's entry into the social environment through the assimilation of his norms, ideals, values, and others ${ }^{2}$.

The process of socialization continues throughout human life, it is an integral part of human ontogenesis. Synogenesis is an integral process of formation and development of a person, including morphological, physiological, mental and social development; This is the formation of man as a conscious social being, as an individual. In psychology distinguish the concept: Development and formation, maturation and establishment, as well as the implementation of personality. Under development, quantitative and qualitative sequential changes (mental or physical), associated with certain stages of life and progressive, leading to improvement. Formation is a purposeful process of personality changes or individual aspects, qualities due to specially organized influences (for example, the formation of economic thinking, the formation of youth spirituality). Maturation the physiological, physical and mental changes of the individual or individual functions and processes due to the effects of internal congenital factors. Formation - indicates the acquisition of new features and forms in the process of personality development (for example, the formation of a creative personality in the context of the psychology of family education). Establishment - the process of self-realization of the needs of the individual, opening new prospects for its development. This new term belongs to Academician Maksimenko S.D. ${ }^{3}$.

Mental development of a person is divided into certain age periods, the consistent change of which is irreversible and unpredictable. Each age period (age) is a peculiar degree of physical, physiological and mental development, with its relatively stable qualitative features inherent to it. For each age period characterized by: a sensitive period, a crisis period, a leading activity. Sensitive period - the most favorable for the development of one or another mental function (For example, from one to three a sensitive period of speech development). Crisis period - a period of rapid and rapid changes in the psyche in one or another age period (for example, the crisis of birth, the crisis of three years, "I-myself", the crisis of adolescence, etc.) Leading activity - the type of activity most characteristic of a particular age period ( For example, emotional and direct 2013. 262 c.

2 Москалець В.П. Психологія особистості: Навч. посібник. - К. : Центр учбової літератури,

${ }^{3}$ Максименко С.Д. Психологія особистості : Підручник. - К. : КММ, 2007. 296 с. 
communication between an infant and an adult [0-1], subject-manipulative activity for young children, role-play plot [3-6 years] $)^{4}$.

Prenatal period (from conception to birth). Individual human history begins not from birth, but from its conception. (Parable of the wise man brought to the newborn by a child: after nine months of the prenatal period, not only the fundamental qualitative and quantitative physical, physiological changes of the future newborn, but also its intense mental development occur. Prenatal development - prenatal, uterine development an individual, during which the expansion of the inherited potential of him is taking place. Its peculiarities are determined by the nature of development at the next stages of the life of the child and even of an adult. An infant in the prenatal period takes place in a strictly controlled environment - the uterus - and overcomes several successive stages, but even in the maternal womb, the external environment affects its development. Almost since conception, the child becomes an element of the situation that is formed in the environment., well-being and lack of stability, stability and shock, health and illness in the family, which expects the child, affect its prenatal development. This is the most important period in human development. After all, a "ready man" is born - in this period all mental functions of the future person are formed (predestination - the innate preconditions for the development of abilities).

Important for normal mental and physical development of the child is the mental and physical state of the mother: positive emotions, proper nutrition, day routine (normal sleep), well-being in the family. This is a necessary condition for the normal development of the child.

Infant (postnatal period). When born, the child physically separates from the mother. It falls into completely different conditions: cold, bright light, air (which was still water), which requires a different type of breathing, changes in the type of food. The newborn baby has its anatomical and physiological features: it has a large head and short legs. The difference in body proportions 1/4 (in a child) and 1/7 (in an adult) is remained in a child up to 1 or 1.5 years.

Each year, the length of the body is increased by $4-5 \mathrm{~cm}$, and the body weight is $1.5-2 \mathrm{~kg}$. In junior pupils, for example, the mass of the brain is 1250-1300 g, which corresponds almost to the weight of an adult. The average mass of the brain in men $-1375 \mathrm{~g}$, in women $-1275 \mathrm{~g}$. In men it is $2 \%$ of the total body weight, in women $-2,5 \%$. For a long time, it was believed that the mental capacity of a person depends on the mass

\footnotetext{
${ }^{4}$ Савчин М.В. Здатності особистості : монографія. Київ: ВЦ «Академія», 2016. 288 с.
} 
of the brain: the greater the mass of the brain, the more gifted man is. But, as it was later, this is not always true. For example, the brain of I. S. Turgenev weighed 2012 gr, and the brain of A. Franz - 1017 gr. The heaviest brain - $2900 \mathrm{~g}$ was found in an individual who lived only 3 years. His brain was functionally inferior. It has been established that human intelligence decreases only when its mass decreases to $900 \mathrm{gr}$ or less. So, there is no direct connection between the mass of the brain and the mental abilities of man. But there was determined the best weight of the brain $(900 \mathrm{~g})$, beyond which the brain is considered to be inadequate.

\begin{tabular}{|l|c|c|c|}
\hline \multirow{2}{*}{ Age } & \multicolumn{3}{|c|}{ Body proportions } \\
\cline { 2 - 4 } & Length of the body & Weight of the body & $\begin{array}{c}\text { Weight } \\
\text { of the cerebrum }\end{array}$ \\
\hline Newly born & $48-52 \mathrm{~cm}$ & $3-3,5 \mathrm{~kg}$ & $-400 \mathrm{gr}$ \\
\hline 1 year & Increase up to $25 \mathrm{~cm}$ & Increase up to 6-7 kg & $800-900 \mathrm{gr}$ \\
\hline 2 years & $\begin{array}{c}\text { Increase up to } 10-15 \\
\mathrm{~cm}\end{array}$ & Increase up to $2-3 \mathrm{~kg}$ & $1000-1100 \mathrm{gr}$ \\
\hline
\end{tabular}

The psychology of the newborn. The development of the psyche of the newborn is based on the basic actions:- sleep (about 20 hours a day) and feeding. Three states of sleep, which occupy most of the time in the life of the newborn, provide rest of the nervous system and the psyche, protect them from exhausting. During calm and active liveleness, the child is receptive to stimulate adults, and crying, shouting expresses their needs. Those who believe that in the first days of life the baby does not hear anything, sees nothing, understands nothing - they are deeply mistaken. For normal mental development it is enough to have mother and father near a cradle (smile, fairy tale, positive music, love and kindness). Japanese scientists proved: they observing the functions of the brain of the newborn ( 3 days) asked one of the women to address the child with affectionate words - no changes in the cerebral cortex were examined. Following her, the same words were spoken by the mother - there was arousal of emotions. There are countries where the smile is not accepted, but people still smile to children up to 1 year.

Kid (from 1 to 3 years old). From 1 year to 3 years - a sensitive period of speech development. If at this age, the child is not amoung people helshe will speak fluently (For example: Mowgli). The vocabulary of a half year old child usually contains about 10 words. A child aged 1 year 8 months knows 50 words, in 2 years - approximately 200. Up to three years the vocabulary is already 900-1000 words. There is a direct relationship between the quality of language stimulation in the home 
environment and the development of the language of the child in 3 years. The critical period in the development of the child's language is the age from 10 months to 1.5 years. It is at this time that you need calm, developing games, and stress is undesirable. At this stage of life, a new relation to the world of things develops: knowledge. At this age, the "dry" theory for the child does not mean anything - the baby must feel all the touch, taste, smell. Of course, there is absolutely no "peaceful" coexistence between adults and children. There are things that usually can not be allowed: pull a lamp switch or other electric appliance (iron, tape recorder, TV), remove from the shelf "adult books", etc. But in this case, the words "can not!" Is a small hope - it only strengthens the persistence of the baby, alerts and excites him! (The crisis of three years, "I myself!"), (For example: feeding a kitten). The crisis of 3 years belongs to the acute. The child is unmanageable, gets irritated. Behavior almost can not be corrected. The period is heavy for both the adult and the child. Negativism - the reaction is not about the content of the proposal of adults, but on the fact that it goes from adults. The desire to do the opposite, even contrary to their own will. Obstinacy. The child insists on something not because he wants, but because he has demanded it, it is bound by his original decision. Obstinacy. She is impersonal, directed against the norms of upbringing, a lifestyle that has developed up to three years. Arbitrariness Aspire to do everything by herself. Protest revolt A child is in a state of war and a conflict with those around him. The crisis proceeds as a crisis of social relations and is associated with the formation of the child's selfawareness. The position "I myself" appears. The child is aware of the difference between "must" and "want". The best way is to make something else attract attention! Leading activity is a game. In the game the child will know the world. Toys are money in the bank. It is important to cultivate good habits - the moral capital laid down by man in his soul (K. Ushinsky). A bad habit is a moral unpaid loan that can lure a person by increasing interest, paralyzing her best endeavors and can lead to moral bankruptcy. Folk phrase of wisdom says: "If you sow your habit - you will harvest the character. Succeed in character - you will harvest fate".

Preschooler (3-6 years). During this period, the child first mastered the so-called cannon movements, motions where the desired result is achieved with the help of an instrument, an instrument (learns to use scissors, tools, writing, hammer, etc.). Innovation is the formation of arbitrary behavior: responsibilities; rights; Rules of Conduct; assimilation of moral norms: empathy, benevolence, sociability, etc. 
Social situation of preschooler development: need for communication with adults and peers (cognitive communication), discussion with adults about actions and behavior of own and other people. Sensitive period of formation of morality (5-7 years), (it is important to lay the Christian principles - catechism - preparation for the first confession and the first solemn Holy Communion).

The preschool child consists of the basics of moral consciousness and behavior in the unity of their cognitive, emotional, evaluative and behavioral components: the level of development of the intelligence of the preschool child is at the basis of the formation of his first moral representations, understanding of ethical norms, their rationality and expediency; Preschooler moral judgments are at the stage of moral realism, reflecting a clear understanding of good and evil, based on the authority of an adult; ethical standards-samples are formed as emotionally-cognitive generalizations about behavioral methods.

Leading activity - role-playing game (game with rules). (For example: Legend of the Honest Word). The harm is "Guerrillas", because children perceive death as death, crying and crying. Up to 7 years is completed the process of mastering the native language! The rapid fantasy, the development of creative imagination, it can not be shaped "you're lying". The original word appears the enthusiasm that Tchaikovsky described in his work "from 2 to 5". (For example: "From the mint sweeties there is a draft in the mouth", "The bald head is a naked", "The husband of a "strykozy"(dragonfly) is a "strykozel"("kozel" in Ukrainian means a goat".)

Junior schoolboy (6 (7) - 9 (10) years). 1. The harmfulness of 6-year education: the inappropriateness of our system (daytime sleep, education in the form of the game); neo-ossification of phalanxes of the fingers (writing is a lot of harm, but molding, drawing - useful); curvature of the spine.

2. A complicated neoplasm and crisis is the assessment(a mark) conflicts between the teacher and the student; It is necessary to form selfesteem - a sensational period of formation of self-consciousness.

3. Leading activity: education.

Memory needs training: use memory laws:

1) not everything at the same time (main);

2) in interest;

3) law of awareness: "I need it";

4) association law; 
5) The law of mental reading.

Thinking requires training (15 minutes to listen to Bach and Beethoven) develops physical and mathematical thinking, it is useful to massage the ends of the fingers, to walk barefoot. Assign creative tasks. (For example, 1. Connect the dots with one line without interrupting your hands. 2. Flies the birds flock. How to count them?)

From what we study - we remember: $10 \%$ of what we hear; $20 \%$ of what we read; $30 \%$ of what we see; $50 \%$ of what we hear and see; $70 \%$ of what we say (we translate); $90 \%$ of what we are doing.

Teenager (10 (11) - 16 (17) years). Adolescence is one of the most important stages of human life. There are many sources and initiatives of all subsequent formation of personality. The age is complex, can be easily hurted, difficult and it turns out that he is more than other periods of life, depends on the reality of the society in which the teenager is formed. Adolescence is also called transitional - it is the age of puberty, changes in the entire endocrine system (genital organs, thymus, thyroid, pancreas, pituitary gland).

This causes a gap in growth, weight gain, chest volume changes face due to the growth of the facial part of the skull. Osteopathy of the spine ends in 21 years, therefore, the load in adolescence is disastrous (it is not necessary to raise the heavy things); finishes with the joints of the pelvic bones (where there are genitals there is no need to wear heels); rapid growth of organs requires a large load of the heart, therefore, the characteristic of this age is increased heartbeat, increased pressure, headaches, dizziness. The rearrangement of the endocrine and nervous system affects the inner (mental) state of the adolescent, which is expressed in imbalance, irritation, anxiety, or vice versa, apathy, tenderness. Not a teenager, but an age is difficult for a teenager. The peculiarity of adolescence is that it has the heart of an adult, and the blood vessels of the the child.

Inner maturing, they feel themselves adults, but they are not yet. Need a disco, because this music excites the lower vibrations, the hormonal system of genital organs. (For example: evening party and a contemporary disco). To protect the teenager from the negative influence of "street", "spoiled" television, erotic, immoral videos - the duty of parents! Example parent (mother) is the only way to educate a teenager. The ideal of God is the ideal of perfection. 1 time a week of Mass the teacher of life (A. Sheptytsky) .1 times a month of confession. 
To become a teenage friend, because the slightest carelessness, distraction, indifference, misunderstanding to the question, request or desire of your child at this age - and you have lost your trust at all. Realize that along with you is not just a kid, but an adult whose interests should be respected. But keep in mind that under this indicative upbringing lies uncertainty and even fear. So do not let the street and someone else, bot not you, become the consolation. Control over a teenager should be. It is better to invite friends to the house than he should be somewhere in the middle of nowhere. You have to go together camping, in a museum, a movie, an exhibition, a concert. If you have a sense of humor all right, on the door to the teenager write "Caution! Teenager!". In this period, it is necessary to grow in them what is called eternal values: the family, the Motherland, the Church, the Confession. The sensational period of formation of self-esteem and its best performer is a confession or a voice of conscience. Remember your origin (roots), customs, traditions, ceremonies and bring it to your children (tree of the pedigree).

Juvenile age (16 (17) - 21 years). At adolescence, the physical development of the organism is essentially completed, puberty is terminated, the cardiovascular system begins to work harmoniously, the rate of growth of the body slows down, muscle strength increases significantly, working efficiency increases, ends the formation and functional development of organs and tissues. Body constitution, especially the face, becomes an adult, specifically individual. Disappears characteristic of teens excitability, imbalance.

Juvenile age is the stage of formation of self-consciousness and of own world outlook, making responsible decisions, human proximity, when the values of friendship, love become paramount. The main feature of this period is the need for a young person to take the internal position of an adult, choose a prof ession (prof essional self-assessor eating), to become a member of society, to develop a worldview (moral selfdetermination), to choose one's way of life. Youth is a unique period of entering the world of culture: theaters, concert halls, museums - these impressions remain for life. All life remains in memory and experiences associated with the first friendship and first love. The most characteristic of this age is the need to love and be loved. "To love is to look not at each other, but to look together in one direction". "That tree does not bear fruit in the fall, which does not bloom in the spring". The call of a woman to be a wife with a mother. There is also a vocation - a monastery - serving God. Pregnancy is not such a beauty, not such a charm. If the basis 
of the relationship between the boy and girl is not friendship, then such relationships are doomed to death. First, unity of souls, and then bodies (marriage - sexual relations) Then there will not be AIDS, sexually transmitted diseases in us. (For example: a meeting with a venereologist in the school № 69) ${ }^{5}$.

Maturity (21 (22) - 65 (70) years). The maturity of the personality is the final result of the work of the individual over himself. Signs of a mature person: Takes full responsibility for his life, for his successes and defeats, for the quality of his life. He cares about his personal growth: he develops his abilities, gets rid of prejudices, changes habits, expands ties, raises his prof essionalism, cares about the growth of self-esteem. Most likely religious. Faith makes a person stronger and noble. He is engaged in interesting creative activity that brings joy. Therefore, he achieves great success in his prof ession. (For example: Solomon's Parable)

Beginning of the elderly (65-70 years). Old age is a period of life that occurs after maturity and is characterized by a gradual relaxation of activity. Characterized by the deterioration of health, mental abilities, and attenuation of the functions of the body. Before this period of life, citizens of many countries (women - from 55-75, men - from 60-75, depending on the country) have the right to retire. But there are also a lot of retired people who work. Old age is divided into several shorter periods of human life: Elderly age - 61-71 for men, 56-74 for women. Older age $-71-90$ for men, 74-90 for women. The age of longevity is more than 90 years old (Table 1$)$.

\section{Psychology of spiritual growth of youth}

Spiritual development of the person was important to mankind in all times and ages. In our time, the spirituality of the individual gains special values. Indeed, without a spiritual rebirth and renewal, the return of spirituality in the souls of men, it is impossible to speak about the revival our society, its conformity with the norms of civilized existence, the legal and real guarantees of rights and freedoms, which are priority throughout the civilized world.

Spiritual development is a long and difficult path to improvement. It awakens abilities, raises consciousness to a new level, strongly transformerait orientation of the personality, which begins to function in new dimensions.

\footnotetext{
${ }^{5}$ Жигайло Н. І. Психологія : навч.-метод. посіб. - Львів : Вид-во «Сполом», 2013. 264 с.
} 
Table 1

Periodization of age development

\begin{tabular}{|c|c|c|c|c|c|}
\hline Period & \multicolumn{2}{|c|}{ Age } & $\begin{array}{l}\text { Crisis } \\
\text { period }\end{array}$ & $\begin{array}{c}\text { Sensational } \\
\text { period }\end{array}$ & Main activity \\
\hline $\begin{array}{c}\text { I } \\
\text { Prenatal } \\
\end{array}$ & \multicolumn{2}{|c|}{$\begin{array}{l}\text { From conception to } \\
\text { birth }\end{array}$} & $\begin{array}{l}\text { Crisis } \\
\text { of birth }\end{array}$ & $\begin{array}{l}\text { Formation } \\
\text { of all mental } \\
\text { functions }\end{array}$ & $\begin{array}{l}\text { Sucking } \\
\text { a finger }\end{array}$ \\
\hline $\begin{array}{c}\text { II } \\
\text { Infant } \\
\text { (postnatal) }\end{array}$ & \multicolumn{2}{|c|}{$0-1$ years } & $\begin{array}{l}\text { Crisis } \\
\text { of birth }\end{array}$ & $\begin{array}{c}\text { Emotional } \\
\text { development }\end{array}$ & $\begin{array}{c}\text { Emotional } \\
\text { direct } \\
\text { communication } \\
\text { with adults }\end{array}$ \\
\hline $\begin{array}{l}\text { III } \\
\text { Baby }\end{array}$ & \multicolumn{2}{|c|}{$1-3$ years } & $\begin{array}{c}\text { Crisis } \\
\text { of three } \\
\text { years } \\
\text { "I myself" }\end{array}$ & $\begin{array}{c}\text { Speech } \\
\text { development }\end{array}$ & $\begin{array}{c}\text { Objectively } \\
\text { manipulative } \\
\text { activity }\end{array}$ \\
\hline $\begin{array}{c}\text { IV } \\
\text { Preschooler }\end{array}$ & \multicolumn{2}{|c|}{$3-6(7)$ years } & $\begin{array}{l}\text { Crisis of } \\
\text { preschooler }\end{array}$ & $\begin{array}{l}\text { Formation } \\
\text { of morality }\end{array}$ & $\begin{array}{c}\text { Storyline } \\
\text { role-playing } \\
\text { game }\end{array}$ \\
\hline $\begin{array}{c}\text { V } \\
\text { Junior } \\
\text { schooler }\end{array}$ & \multicolumn{2}{|c|}{$6(7)-9(10)$ years } & $\begin{array}{l}\text { Crisis of } \\
\text { junior } \\
\text { schooler }\end{array}$ & $\begin{array}{c}\text { Formation } \\
\text { of learning } \\
\text { skills }\end{array}$ & $\begin{array}{l}\text { Storyline } \\
\text { role-playing } \\
\text { game } \\
\text { Education } \\
\end{array}$ \\
\hline $\begin{array}{c}\text { VI } \\
\text { Junior } \\
\text { teenager }\end{array}$ & $\begin{array}{l}\text { girls } \\
10-12 \mathrm{y} .\end{array}$ & $\begin{array}{c}\text { boys } \\
11-13 \mathrm{y} .\end{array}$ & \multirow{3}{*}{$\begin{array}{c}\text { Crisis } \\
\text { of teenage }\end{array}$} & \multirow{3}{*}{$\begin{array}{l}\text { Maturing } \\
\text { Ideology } \\
\text { establishment }\end{array}$} & \multirow{3}{*}{ Education } \\
\hline Teenager & $12-14 \mathrm{y}$. & $13-15 \mathrm{y}$. & & & \\
\hline $\begin{array}{c}\text { Older } \\
\text { teenager }\end{array}$ & $14-16 \mathrm{y}$. & $15-17 \mathrm{y}$. & & & \\
\hline $\begin{array}{c}\text { VII } \\
\text { Youth }\end{array}$ & $\begin{array}{c}\text { Girls } \\
16-18 \mathrm{y} .\end{array}$ & $\begin{array}{c}\text { Boys } \\
17-19 \text { y. }\end{array}$ & \multirow{2}{*}{$\begin{array}{l}\text { Crisis } \\
\text { of youth }\end{array}$} & \multirow{2}{*}{$\begin{array}{c}\text { Career } \\
\text { choosing }\end{array}$} & \multirow{2}{*}{$\begin{array}{l}\text { Education } \\
\text { Work }\end{array}$} \\
\hline $\begin{array}{l}\text { Older } \\
\text { youth }\end{array}$ & $18-21 \mathrm{y}$ & $19-21 \mathrm{y}$. & & & \\
\hline $\begin{array}{c}\text { VII } \\
\text { Beginning }\end{array}$ & \multicolumn{2}{|c|}{$21(22) \mathrm{y}}$. & \multirow{3}{*}{$\begin{array}{l}\text { Crisis of } \\
\text { adultness }\end{array}$} & \multirow{3}{*}{$\begin{array}{c}\text { Self- } \\
\text { establishment } \\
\text { Establishment } \\
\text { of ideas }\end{array}$} & \multirow{3}{*}{$\begin{array}{l}\text { Work } \\
\text { Creative } \\
\text { activity }\end{array}$} \\
\hline of maturity & \multicolumn{2}{|c|}{$30-50 \mathrm{y}}$. & & & \\
\hline $\begin{array}{c}\text { Older } \\
\text { maturity }\end{array}$ & $\begin{array}{r}\text { Women } \\
55-65 \text { y. }\end{array}$ & $\begin{array}{c}\text { Men } \\
60-70 \text { y. }\end{array}$ & & & \\
\hline $\begin{array}{c}\text { IX } \\
\text { Beginning } \\
\text { of elder age }\end{array}$ & $\begin{array}{c}\text { Women } \\
65 \mathrm{y} \text {. }\end{array}$ & $\begin{array}{l}\text { Men } \\
70 \mathrm{y} .\end{array}$ & $\begin{array}{l}\text { Crisis of } \\
\text { elderness }\end{array}$ & Aging & $\begin{array}{l}\text { Creative } \\
\text { vacation }\end{array}$ \\
\hline
\end{tabular}

Youth as subject and object of spiritual culture, to their advantage, values, orientations, needs, actions reflects the level of spiritual culture the society in which she lives. At the same time adaptation to the spiritual culture develops spiritual needs, forms of intellectual and aesthetic interests the person reflects the inner wealth, the measure of spiritual maturity, that is, level personal qualities, which is called spirituality. 
The issue of spirituality the subject of many studies: from Plato Aristotle, Panflu Yurkevich, Gregory Skovoroda to the present day: S. D. Maksymenko, I. D. Pasichnyk, G. A. Ball, M. Th. Boryshevskyi, V. P. Moskalets, M. V. Savchyn, V. F. Morhun, V. M. Zhukovskyi, R. V. Kalamazh, O. V. Matlasevych, A. I. Pashuk, V. P. Melnyk, N. I. Zhyhailo; foreign scientists: F. Lersh, K. H. Jung, K. Rodzhers, R. Meio, Dzh. Konnors and the like. At all times gave large value of spirituality; researchers considered that a concept "spirituality" is to the derivatives from a word "spirit", that means movable air breathing of breathing, transmitter of life. According to the teachings of scientists, spirituality is General cultural phenomenon that encompasses not only the abstract theoretical values and ideals, but also acts according to conscience, truth, and beauty ${ }^{6}$.

Analysis of recent publications on the subject of the study. In modern Ukrainian psychology the study of spirituality in the following key directions: philosophical and relgium, the subject of which is spirituality as perfection of faith in supernatural forces (G. S. Skovoroda, T. Shevchenko, I. Franko, V. A. Sukhomlinsky, G. P. Vashchenko) cultural, the context in which spirituality acts as a way of semestrielle personality within the cultural world through self-determination and samospravny person involves not only knowledge but also feelings, interpretation of reality, the ability to empathy (P. R. Ihnatenko, V. L. Pluzhnyi, M. I. Piren, V. V. Moskalenko, V. V. Rybalka); sociopsychological, in which spirituality is regarded as a multidimensional socio - historical phenomenon, specificity manifestations which are due to the uniqueness of world history as a polycentric education (H. S. Kostiuk, S. D. Maksymenko, M. I. Boryshevskyi, M. V. Savchyn, V. F. Morhun, V. P. Moskalets, H. O. Ball, I. D. Pasichnyk, V. M. Zhukovskyi, R. V. Kalamazh, O. V. Matlasevych, V. P. Melnyk, N. I. Zhyhailo) ${ }^{7}$.

The purpose of the study is to establish psychological patterns and mechanisms of spiritual formation and implementation of the individual student youth.

Presentation of the basic material. Trying to realize the specified purpose and to fulfill the objectives of the study, we proceeded from the fact that spirituality as an integrative quality of personality, is one of the most fundamental personality characteristics as an open system.

\footnotetext{
${ }^{6}$ Жигайло Н.І. Психологія духовного становлення особистості майбутнього фахівця : Монографія. Львів : Видавничий центр ЛНУ імені Івана Франка, 2008336 с.

${ }^{7}$ Максименко С.Д. Генеза здійснення особистості : наук. монографія. - К. : КММ, 2006. 255 с.
} 
In our opinion, spirituality is a complex mental phenomenon; the manifestation of inner world of a person; energy-informational structure personality rich characters that it has. Spirituality is specific features of the personality of the two fundamental requirements: the ideal the needs of learning and social needs to live and act for others.

Under the spiritual formation of personality, we mean the heritage of spiritual values, of religious consciousness and of consciousness of the person; the development of her spiritual priorities; support the system of values to form the basis of life, to be at the forefront of the process activities. Sources of spirituality are the science, culture, religion, art and the like.

Despite the centuries-old experience of spiritual education, the growing its importance in Ukrainian society, Lviv regional branch AllUkrainian public organization "The Society of psychologists of Ukraine" designed and developed a holistic system of formation of spirituality of the individual students.

With the purpose of formation of spirituality of the personality of young people we propose:

1. The concept of "spiritual personality".

2. The author's psychological structure and spiritual personality.

3. The author's model of spiritual identity formation of young people.

4. The training programme of development of spirituality of the individual.

5. Thematic plan of the discipline "Psychology of the formation of spirituality personality".

6. Criteria for the development of spirituality of the individual.

7. The sources of spirituality of the individual.

Under the phenomenon of "spiritual personality" understand such a person, in which lit a spark of Deity; who in their thoughts and actions based on the Law Of God; which in my life is guided by the postulate: "I have been working on Forever!, and not just always work!" Person for a flight you want not the feathers, and the power of the spirit! Strong spirit, national consciousness, intellectually developed, scientifically savvy young need personalities each nation, each state, each industry. Therefore, an integral component of the personality of young people must be spiritual - the lead line of its activities.

The author's psychological structure, spiritual identity (Pic. 1) presented in the form of a tree, the base (root) which is based on the factors of self-regulation, which are the will, conscience, and faith; 
the branches of this tree is our cognitive and emotional-volitional mental processes, mental state, mental properties, mental activity, orientation and the like, and the tip of this wood is committed to know God, that is, to self-improvement ${ }^{8}$.

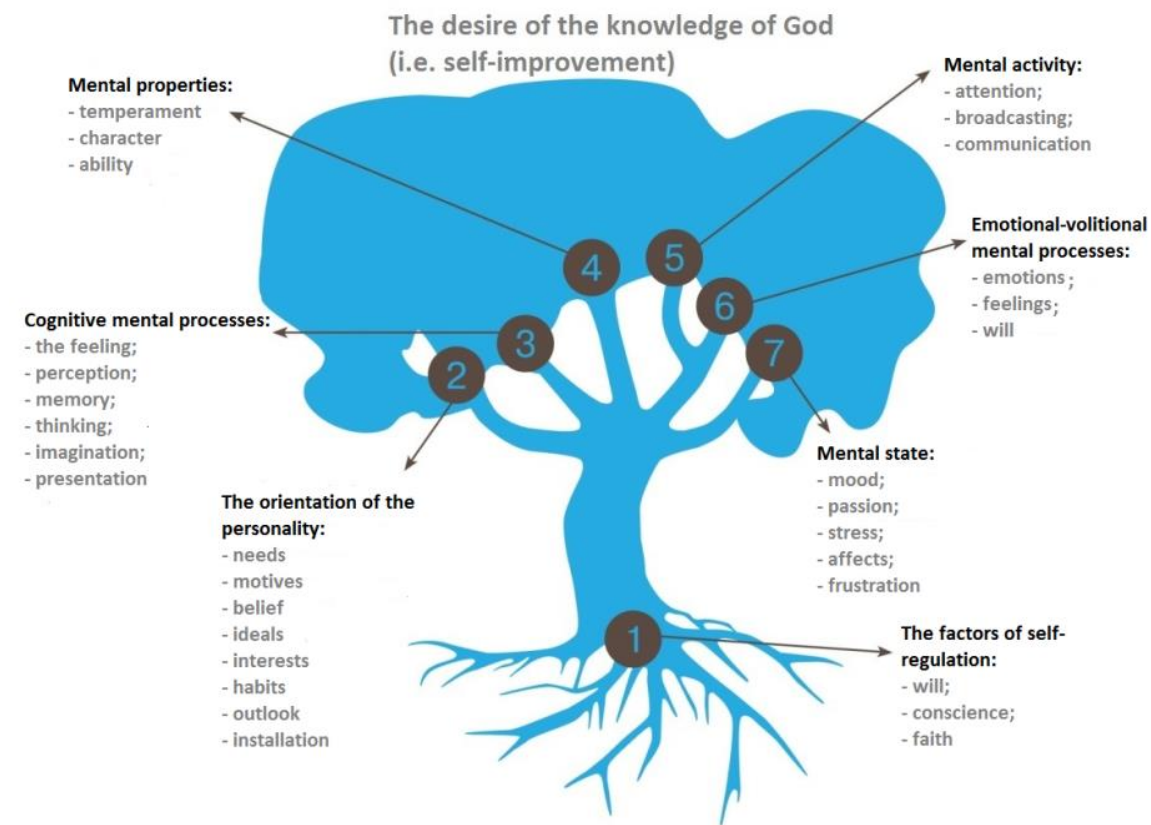

Pic. 1. Psychological structure of personality by S. D. Maksymenko, N. I. Zhyhaylo

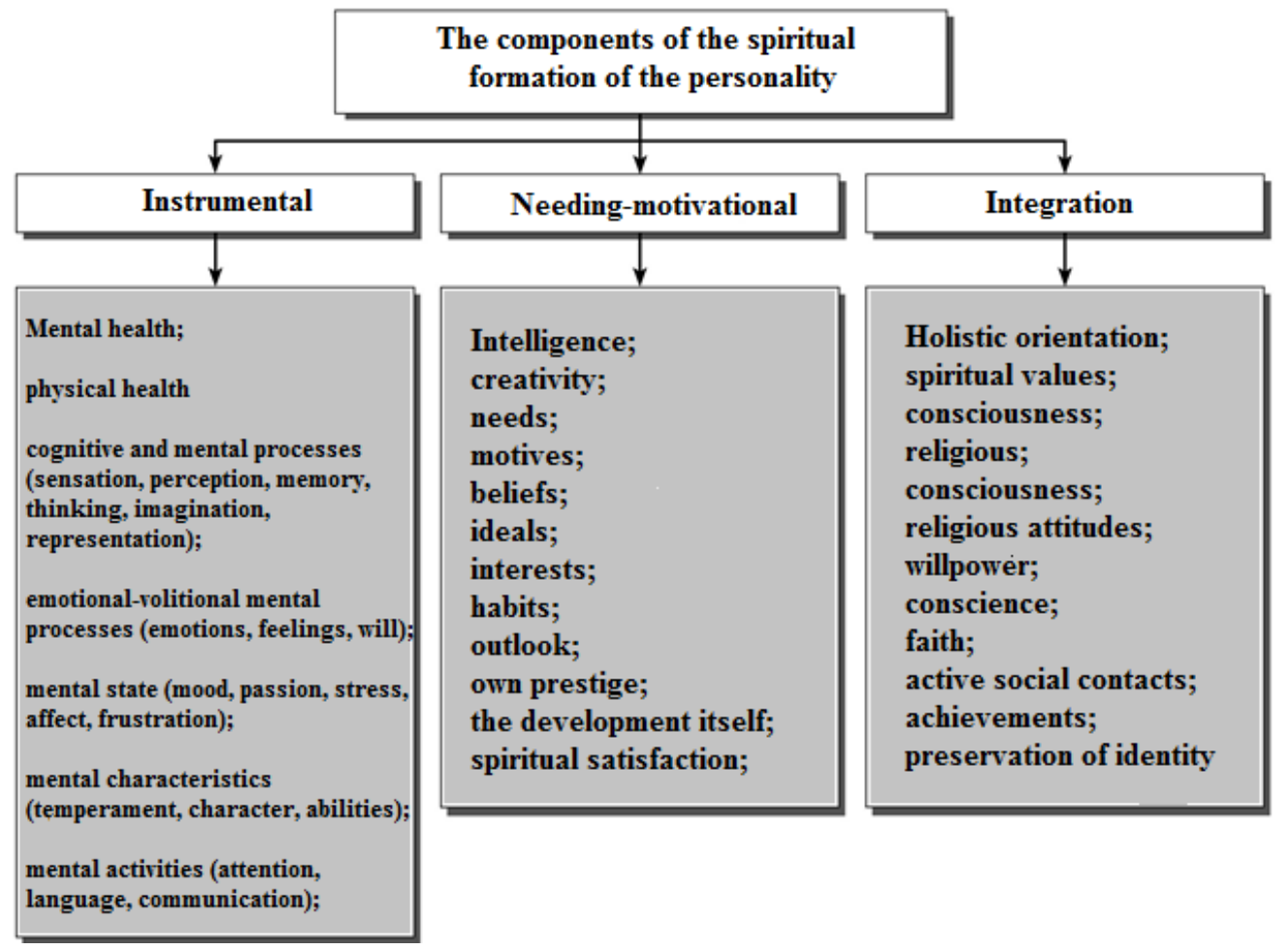

\section{Pic. 2. The author's model of spiritual identity formation}

\footnotetext{
${ }^{8}$ Максименко С.Д. Психологія особистості : Підручник. Київ : КММ, 2007. 296 с.
} 
The author's model of spiritual formation of the personality includes instrumental, needing-motivation and integration components (Pic. 2).

We also proposed the formation of spiritual psychological training individual students. Structurally "Training program developmen spiritual person" is divided into seven topics-blocks. Each block the original exercises and training exercises are modified (other researchers) which can be used according to the goal. We used: role and business games, a mini-debate with exercise training personal growth exercises with bodyoriented training, lectures, scientific seminars, round tables, conferences, pilgrimages, retreats and more. The list of blocks and psycho-pedagogical and training tools to each of them is given in table 2 .

Table 2

\section{"The training program of the spiritual development of the personality"}

\begin{tabular}{|c|c|c|}
\hline $\begin{array}{c}\text { № } \\
\text { block }\end{array}$ & $\begin{array}{l}\text { Name training } \\
\text { the block }\end{array}$ & Major psychologic-educational and training facilities \\
\hline 1 & $\begin{array}{l}\text { Introduction to } \\
\text { the work }\end{array}$ & $\begin{array}{l}\text { Introduction to the rules of the T-group. } \\
\text { The formation of an atmosphere of psychological safety. } \\
\text { Psyhohimnastyka. }\end{array}$ \\
\hline 2 & $\begin{array}{l}\text { The value } \\
\text { orientation } \\
\text { of the manager }\end{array}$ & $\begin{array}{l}\text { Projective picture "me and my place in the world of men". } \\
\text { Roleplay "Bad people are good people. What's } \\
\text { the difference?". } \\
\text { Business game "draw up a code of conduct for the } 21 \text { st } \\
\text { century". } \\
\text { Exercises on the removal of "clips" in the muscles and } \\
\text { increase the level of security in the T-group. }\end{array}$ \\
\hline 3 & $\begin{array}{l}\text { Spiritual } \\
\text { development } \\
\text { manager }\end{array}$ & $\begin{array}{l}\text { Role play "I - past, present, future. What is } \\
\text { the difference?". } \\
\text { Psychological workshop "What I am most proud of in } \\
\text { your past? That was such that it would be to live } \\
\text { differently?" } \\
\text { Exercise "empty chair - my friends and enemies in } \\
\text { the past." } \\
\text { Brain storminh "Defining areas of social support by } \\
\text { the state as manager of the future creator." } \\
\text { Exercises removal "clips" in the muscle expression } \\
\text { expression through movement. }\end{array}$ \\
\hline 4 & $\begin{array}{l}\text { Religious values } \\
\text { manager }\end{array}$ & $\begin{array}{l}\text { Socio-perceptual training focused on personal growth "I - } \\
\text { the eyes of others. Can you trust me?" } \\
\text { Panel discussion "The man who actively believes in God - } \\
\text { who is she? Past, present, future?" } \\
\text { The business game "Sacred If I wrote a book?" } \\
\text { Exercises removal "clips" in the muscle expression } \\
\text { expression through movement. }\end{array}$ \\
\hline
\end{tabular}


Table 2 (continuance)

\begin{tabular}{|c|c|l|}
\hline 5 & $\begin{array}{c}\text { Religious } \\
\text { consciousness } \\
\text { manager }\end{array}$ & $\begin{array}{l}\text { Discussion "Religious conscious man - "for "and } \\
\text { "against"." } \\
\text { Brain-storminh "Who am I - a grain of sand, water drop, } \\
\text { dunovinnya breeze - or I answer for the future?" } \\
\text { The business game "conscience. Do you need it in the 21st } \\
\text { century?" } \\
\text { Exercises removal "clips" in the muscle expression } \\
\text { expression through movement. }\end{array}$ \\
\hline 6 & $\begin{array}{c}\text { Discussion } \\
\text { of the results } \\
\text { of the training }\end{array}$ & $\begin{array}{l}\text { Discussion "I started in T-group. I - after work in a T- } \\
\text { group. What has changed in me?" } \\
\text { Exercises on the removal of "clips" in the muscles, } \\
\text { the manifestation of expression through movement. }\end{array}$ \\
\hline 7 & $\begin{array}{c}\text { The final lesson } \\
\text { "My Future" }\end{array}$ & $\begin{array}{l}\text { Formation existential "I" } \\
\text { Disconnection sense of "we" in training participants. } \\
\text { Exercises removal "clips" in the muscle expression } \\
\text { expression through movement. }\end{array}$ \\
\hline
\end{tabular}

Based on psychological training formed the idea that a young person is at the stage of spiritual development when it: firstly, finds meaning that corresponds spiritual ideals and what it has at the same time opportunities; secondly, has developed relevant traits, knowledge and skills that allow you to achieve this goal, realize themselves in their spiritual formation.

At a later stage of the study we have proposed a comprehensive "Program of spiritual formation and implementation of personality", which provides diagnostic and remedial work that gives the opportunity to assess the level of spirituality of the individual and contribute to its promotion. The program included the formation of a system of values as the basis of spiritual formation and implementation of an individual; the allocation of religious values as an important factor of spiritual development of personality; training as an effective method of forming of spiritual values of the individual; the allocation of the religious consciousness as the essential component of spirituality of the individual; lectures on the special course "Psychology of spiritual formation and implementation of the person".

To study assessing the level of spirituality in our students conducted an experiment. Contingent study were young people studying in higher education institutions of Lviv, studied 305 people over the years of study at the university.

Young people with a high level of spirituality and the appropriate level of self-regulation is not a particular problem for teachers, and it is self-disciplined, law-abiding and trying to meet the demands of training. The desire to develop the individual desires to expand its capacity 
in accordance with a focus on model - "the best that I can be" contributes to spiritual development, personal growth person.

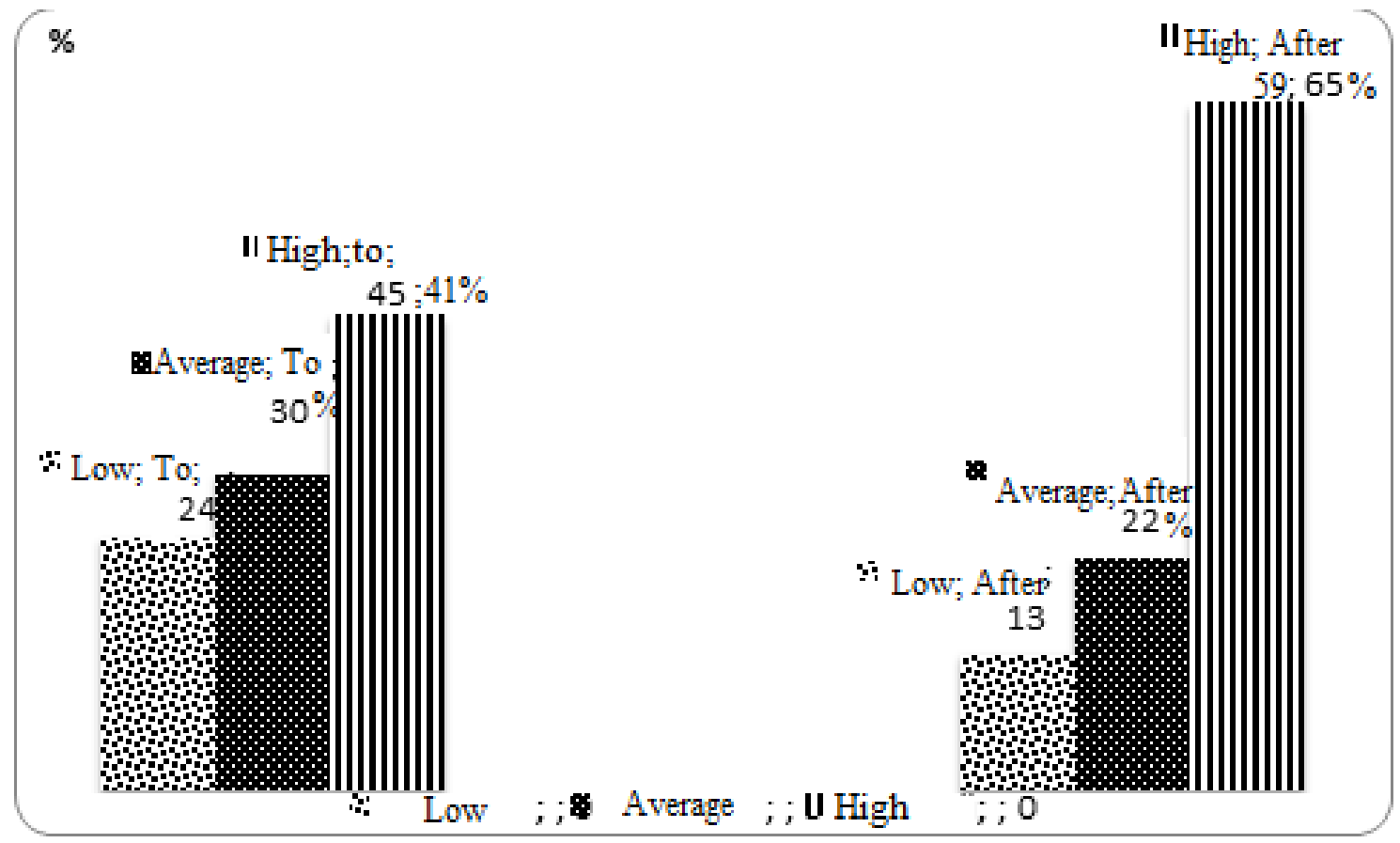

Pic. 3. The level of development of spirituality of students ("before" and "after" implementing programs of spiritual formation and implementation of the individual)

Meaningful indicators studied characteristics

Table 3 (Based on correlation analysis)

\begin{tabular}{|c|c|c|c|c|c|c|c|c|c|}
\hline & PA & SA & LS & CV & LE & LR & MV & RA & LI \\
\hline PA & 1,000 & 0,757 & $-0,710$ & 0,537 & $-0,637$ & $-0,564$ & 0,642 & $-0,708$ & $-0,384$ \\
\hline SA & 0,757 & 1,000 & $-0,705$ & 0,525 & $-0,582$ & $-0,498$ & 0,580 & $-0,712$ & $-0,355$ \\
\hline LS & $-0,712$ & $-0,705$ & 1,000 & $-0,615$ & 0,589 & 0,745 & $-0,657$ & 0,626 & 0,473 \\
\hline CV & 0,537 & 0,525 & $-0,615$ & 1,000 & $-0,613$ & $-0,461$ & 0,611 & $-0,619$ & $-0,514$ \\
\hline LE & $-0,637$ & $-0,582$ & 0,589 & $-0,613$ & 1,000 & 0,557 & $-0,574$ & 0,499 & 0,583 \\
\hline LR & $-0,563$ & $-0,498$ & 0,744 & $-0,460$ & 0,557 & 1,000 & $-0,623$ & 0,591 & 0,586 \\
\hline MV & 0,641 & 0,580 & $-0,657$ & 0,611 & $-0,574$ & $-0,623$ & 1,000 & $-0,677$ & $-0,498$ \\
\hline RA & $-0,707$ & $-0,711$ & 0,626 & $-0,619$ & 0,499 & 0,591 & $-0,677$ & 1,000 & 0,522 \\
\hline LI & $-0,384$ & $-0,355$ & 0,473 & $-0,514$ & 0,583 & 0,586 & $-0,498$ & 0,522 & 1,000 \\
\hline
\end{tabular}

\section{Legend:}

PA - personal anxiety; SA - situational anxiety; LS - the level of spirituality; CV - chaos values; LE - the level of empathy; LR - the level of religiosity; MV- material values; RA - religious attitudes; LI - level of intelligence. 
The feature students from middle-spirituality is that they prefer the personal experience of the beliefs of others. So mentor for these people it is important to update the connection between their own life experiences and spiritual values. Young people with an average level of spirituality necessary general measures which will give an opportunity to the young man to survive in action experience, which can then be discussed in the discussions, round tables during conversations, etc. The path from his own experience through reflection and generalization in harmony positivity and negativity awareness for further implementation details - constructive way interaction with the person in the direction of her spirituality.

The characteristic of people with a low level of spirituality is the advantage of wealth over spiritual. Consequently, such individuals is important to help see life alternatives, encourage them to choosing ideals emphasize the spiritual aspects of life. An instructor is advisable to update aspects of moral behavior, citing the experience familiar to the young person or the immediate environment, and illustrate promising action that might confirm this idea.

Comparing the distribution levels of spirituality student "before" and "after" of the program of spiritual identity formation (Pic. 3) illustrate the effectiveness of the applied program. In particular, share a high level of spirituality among young people has increased by 20\% (as a result of the program of spiritual formation of personality).

We performed a correlation analysis of the results, in particular the dependence and mutual influence between: level of spirituality and intelligence; level of spirituality and empathy; level of spirituality and level of reactive anxiety; level of spirituality and level of personal anxiety; level of spirituality and religiosity level; level of spirituality and religious level installations; level of spiritual and material values, etc. (Table 3).

We also presented the criteria to be met by spiritual identity: moral: spiritual personality to be a religious man; be a practicing christian; have an objective and a subjective authority; love their work and respect his work; be fair; to have a moral and business tact, and the joy of communicating; intelligent: high level of training; the accuracy of memory, flexibility of thinking, creative imagination; temperament, labile nervous system (the innate factors), will power and belief (acquired factors), speech culture, rhetoric; intuition; observation; physical and canonical: clothing, posture, behavior, generosity, spirituality. 


\section{CONCLUSIONS}

The book of books - the Sacred Scripture, Theology (science of God); Holy Liturgy is the teacher of life (A. Sheptytskyi); Prayer the soul's development; church art; christian philosophy (knowledge of God); nature, culture, art, sport and other.

The adoption and flourishing of our state is possible only if the prof essional and spiritual formation and implementation of every citizen, a prof essional, a specialist, who should become the decisive force which will ensure the irreversibility of the movement of Ukraine to his will and glory, the economic and social well-being, a healthy nation, a strong state of the european level.

\section{SUMMARY}

The article is devoted to the clarifying of psychological aspects of personal and spiritual growth of youth. The object of this study is the process of personal and spiritual formation of student youth. Subject of research: psychological patterns and mechanisms of personal and spiritual growth of personality in adolescence. The aim of the study is to establish the psychological patterns and mechanisms of personal and spiritual formation of youth.

The scientific novelty of the research is: in the development and approbation of the model of spirituality of the personality; in establishing the criteria, levels and indicators of spirituality of the personality in adolescence; in revealing the psychological patterns of the spiritual formation of the personality in the period of youth; in the development and experimental approbation of the spiritual development of the student's personality; in the development and approbation within the limits of the given program of the complex diagnostic-correction system.

\section{REFERENCES}

1. Максименко С.Д. Генеза здійснення особистості : наук. монографія. - Київ : КММ, 2006. 255 с.

2. Максименко С.Д. Психологія особистості : Підручник. - Київ : KMM, 2007. 296 c.

3. Москалець В.П. Психологія особистості: Навч. посібник. Київ : Центр учбової літератури, 2013. 262 с.

4. Савчин М.В. Духовний потенціал людини : монографія. ІваноФранківськ: Вид-во «Плай» Прикарпатського ун-ту, 2001. 203 с. 
5. Савчин М.В. Здатності особистості : монографія. Київ: ВЦ «Академія», 2016. 288 с.

6. Жигайло Н.І. Психологія духовного становлення особистості майбутнього фахівця : Монографія. Львів : Видавничий центр ЛНУ імені Івана Франка, 2008. 336 с.

7. Жигайло Н.І. Психологія : навч.-метод. Посіб. - Львів : Вид-во «Сполом», 2013. 264 c.

\section{Information about the author:}

Zhyhaylo N. I.

Doctor of Psychology, Professor of Management Department of the Ivan Franko National Universiti of Lviv 1, Universytetska str., Lviv, 79000, Ukraine

Snyadanko I. I.

Doctor of Psychological Sciences, Associate Professor, Head of Theoretical and Applied Psychology Department of the National University "Lviv Polytechnic" 12, Stepana Bandery str., Lviv, 79000, Ukraine

Hrabovska S. L.

$\mathrm{PhD}$, Professor, Head of the Department of Psychology of the Ivan Franko National University of Lviv 1, University str., Lviv, 79000, Ukraine 